
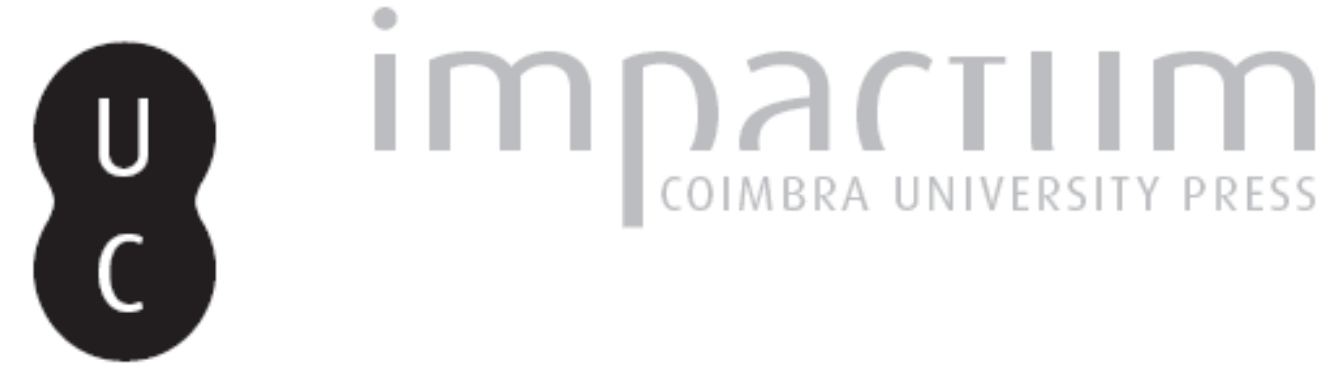

\title{
The battle of giants: the collision of EU and Russian foreign policies towards the contested neighbourhood and the Ukrainian crisis
}

Autor(es): Dias, Vanda Amaro

Publicado por: Imprensa da Universidade de Coimbra

URL persistente:

URI:http://hdl.handle.net/10316.2/43547

DOI:

DOI:https://doi.org/10.14195/1647-6336_18_5

Accessed : $\quad$ 26-Apr-2023 08:52:47

A navegação consulta e descarregamento dos títulos inseridos nas Bibliotecas Digitais UC Digitalis, UC Pombalina e UC Impactum, pressupõem a aceitação plena e sem reservas dos Termos e Condições de Uso destas Bibliotecas Digitais, disponíveis em https://digitalis.uc.pt/pt-pt/termos.

Conforme exposto nos referidos Termos e Condições de Uso, o descarregamento de títulos de acesso restrito requer uma licença válida de autorização devendo o utilizador aceder ao(s) documento(s) a partir de um endereço de IP da instituição detentora da supramencionada licença.

Ao utilizador é apenas permitido o descarregamento para uso pessoal, pelo que o emprego do(s) título(s) descarregado(s) para outro fim, designadamente comercial, carece de autorização do respetivo autor ou editor da obra.

Na medida em que todas as obras da UC Digitalis se encontram protegidas pelo Código do Direito de Autor e Direitos Conexos e demais legislação aplicável, toda a cópia, parcial ou total, deste documento, nos casos em que é legalmente admitida, deverá conter ou fazer-se acompanhar por este aviso.

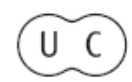




\section{DEBATER \\ A EUROPA}

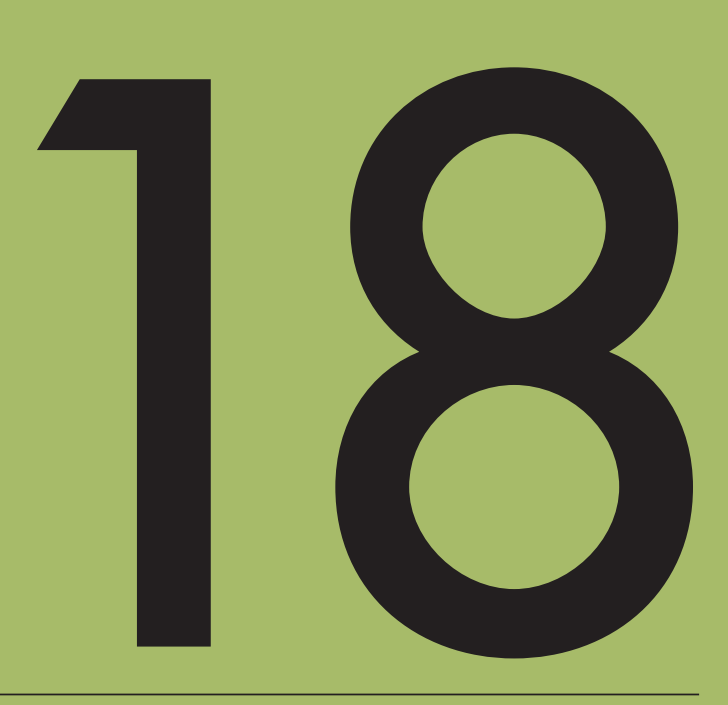

jan-jun 2018

RELACCÕES EXTERNAS DA

UNIÃO EUROPEIA A LESTE

EXTERNAL RELATIONS OF THE

EUROPEAN UNION TOWARDS THE EAST 


\title{
The battle of giants: the collision of $E U$ and Russian foreign policies towards the contested neighbourhood and the Ukrainian crisis
}

\author{
Vanda Amaro Dias \\ Núcleo de Relações Internacionais, Faculdade de Economia \\ da Universidade de Coimbra \\ vandadias@fe.uc.pt
}

\begin{abstract}
:
This paper critically interprets the international dimension of the Ukrainian crisis to reflect upon dynamics of power and security in the broader European space. It argues this crisis to be simultaneously the result and the intensifier of the collision of antagonist and mutually exclusive foreign policies towards the contested neighbourhood by the EU and Russia. For that purpose, it provides an overview of EU and Russian policies towards this region, followed by the discussion of the Ukrainian crisis in the midst of what can be considered to be a battle of giants for regional power and security.
\end{abstract}

Keywords: Contested neighbourhood; European Union; Russia; Security; Ukrainian crisis.

\section{Introduction}

The Ukrainian crisis is arguably one of the most pressing events in the broader framework of post-Cold War European security. It challenged the argument that the Nobelawarded European Union (EU) had successfully maintained peace in Europe and triggered fears about the possibility of violence escalation at the regional level. Notwithstanding its internal dimension related to the incomplete transition of the country after its independence and the persistence of structural problems, such as nepotism, corruption, abuse of power and human rights' violations, this paper argues that the Ukrainian crisis has a clear international dimension to it. When analysed from an international perspective, the tumultuous events that started in Kiev in November 2013 cannot be dissociated from the competition between the EU and Russia for power and security in their shared neighbourhood. 
Arguably, countries in Eastern Europe and the South Caucasus have been central to the regional strategies of both Brussels and Moscow from the early 1990s onwards. The end of the Cold War induced significant changes on dynamics of power and security across the broader European space. As the EU and Russia developed mechanisms to cope with this new reality and redefine their regional and security agendas it became clear that internal and external security were indissociably linked. Therefore, new frameworks for relations were developed aiming at assuring that external threats would not destabilise their respective internal orders, and that their power could create sources of influence beyond their borders thus allowing for the regional projection of these actors and the establishment of a first line of defence from the outer world. During the 1990s, EU and Russian policies towards this region were rather low profile mainly due to internal dynamics. Whereas the EU was very much focused on developing its foreign policy competences and preparing the Eastern enlargement; Russia was engaged in solving issues inherited from more than 40 years of global bipolar confrontation and the manifold challenges deriving from the disintegration of the Soviet Union - including political instability, economic crisis, social turmoil and the lack of agreement between political elites (e.g. Eurasianists, Atlanticists and Nationalists) (White, 2012, pp. 305-318).

Since the EU's Eastern enlargement in 2004, the EU and Russia share a common neighbourhood in Eastern Europe and the South Caucasus. If until then their projection of power towards these regions had been secondary to other political and security concerns, now this space becomes an area of contested interests by the EU and Russia something that has had important consequences for the dynamics of power produced by and reflected in interactions between these two regional giants. As a result, the EURussia-shared neighbourhood triangle has been marred by several struggles for power conferring and antagonistic tone to relations between Brussels and Moscow. This paper envisages to critically analysing these struggles for power by focusing on the Ukrainian crisis as simultaneously the result and the intensifier of dynamics of power and security in the EU-Russia-contested neighbourhood triangle.

In order to delve into this complex topic, the paper starts by providing an overview of EU frameworks for relations with countries in Eastern Europe and the South Caucasus. The second part of the paper presents the main foreign policy tools used by Russia to engage countries in its near abroad and boost its regional influence. The third part of the paper puts these conflicting approaches into comparison and uses the Ukrainian crisis to illustrate how antagonistic interests and strategies towards the same drove the EU and Russia into a route of collision. The final part of the paper focuses on the Ukrainian crisis as an event leading to the intensification of the EU-Russia dispute for influence over an area of common interests and a more vocal mutual-demonization that has increasingly gained the contours of a regional battle of giants between Brussels and Moscow. 


\section{EU Neighbouring Policies Eastwards: From Subtle Partnerships to Powerful Associations}

The post-Cold War geopolitical landscape posed important challenges to the EU and encouraged the development and consolidation of a foreign policy dimension in order to prevent eventual scenarios of political volatility and economic chaos to contaminate its internal stability. However, during the 1990s and early 2000s, EU foreign policies were at a very embryonic stage and the great bulk of attention on regional issues was devoted to the Enlargement process. For these reasons, EU political and economic relations with the post-Soviet space were essentially kept at a technical level and security issues seldom figured on the agenda.

Relations with countries within this area were legally framed by Partnership and Cooperation Agreements (PCAs) signed during the 1990s. Based on a commitment to promote international peace and security, PCAs provided frameworks for cooperation in several areas, from political dialogue and economic cooperation, to culture, science and technical assistance (Partnership and Cooperation Agreement between the European Communities and their Member States, and Ukraine, 1998). At a first glance, PCAs are mainly technical and economic documents. A more in-depth analysis, however, makes visible their entrenched political nature operationalised by a number of evolutionistic and conditionality-driven clauses aiming at promoting greater integration into the EU. Conditionality mechanisms worked along a socialising axis promoting the internalization of EU norms and values by partner states. Together, these strategies gave PCAs the potential to become a powerful tool shaping the Union's political environment in its vicinity (Börzel, Stahn, \& Pamuk, 2010, pp. 140-142). Due to EU internal political dynamics - focus on the development of new foreign policy instruments and on the Enlargement process -, and to internal challenges experienced by post-Soviet states following their independence - the arduous quadruple transition they had to engage with (Kuzio, 2001) -, PCAs never reached their full potential, thus failing to achieve their political and economic goals (Ghazaryan, 2010, p. 226).

Despite the initial impetus to develop channels for relations with countries in the post-Soviet space, the EU remained a rather subtle player in the region until the launch of the European Neighbourhood Policy (ENP) in 2003. As the Eastern enlargement came to completion, the EU started to shift its focus of attention on foreign policy issues to countries in Eastern Europe and the South Caucasus (Casier, 2012, pp. 32-33). Awareness of the - perceived - risk of contagion of security issues in the EU's new neighbourhood gradually paved the way for affirming the EU as a regional player and security provider.

The reasoning was straightforward. The EU needs to assume its responsibility as a 'real global player' by developing a 'proximity policy' centred on the Union's power of attraction (Prodi, 2002) in order to secure the environment at its new vicinity. This was due to the fact that 'stability, prosperity, shared values and the rule of law along our borders 
are fundamental for our own security' and thus 'failure in any of these areas will lead to increased risks of negative spill over on the Union' (Patten \& Solana, 2002, pp. 1-2). Progressively, a trend emphasising the indissoluble nature of internal and external aspects of security (European Council, 2003) became more pronounced in EU discourses and official documents cementing the central rationale of EU neighbouring strategies as an extension of inner security concerns for the promotion of prosperity, stability and security abroad is seemingly driven by the necessity to prevent regional events and disturbances from contaminating the EU's internal order (Averre, 2009, pp. 1693-1694).

As a result, the ENP emerged as the new framework for relations with neighbouring countries from a clear security standpoint, something that represented a move forward regarding the subtle nature of political and security issues as framed by PCAs. The security-oriented nature of the ENP is something hardly contested in the literature on the topic (see e.g. Attinà, 2004; Averre, 2010; Christou, 2010; Dias, 2013). This becomes clear in the analysis of its foundational documents were the goals of creating a 'ring of friends', 'avoid new dividing lines in Europe' and 'promote stability and prosperity' across the broader European space are clearly stated, thus rendering visible the primary intention of protecting the EU from external threats (European Commission, 2003). The evolution of the ENP has also confirmed this emphasis on security as it appears as the dominant narrative, thus performing a structural role in the development and deployment of this policy and related initiatives from inception (Cianciara, 2017).

This self-interested ambition to secure the environment at the EU's borders has an important transformative dimension. Privileged relations promoting political and economic stability in the neighbourhood were based on the export of the Union's liberal model and on the EU's ability to unilaterally dictate what is normal and acceptable (Boedeltje \& van Houtum, 2011; Nilsson \& Silander, 2016). Nonetheless, the potential to do so was compromised by the unwillingness of European elites to include any membership prospects under the framework of the ENP (European Commission, 2004, p. 3) or to accommodate a more agential role by neighbouring countries in the design and development of this policy.

Such transformative impetus sheds light on the structural and powerful nature of the ENP. However, limited political achievements under this framework for relations - e.g. the lack of democratic improvements in Eastern Europe and the South Caucasus, the Russian-Georgian war in 2008, the dire economic crises experienced by countries in the region in 2009, as well as the vulnerability of energy supplies from the mid-2000s onwards - reinforced EU claims that security, stability and economic development remained key challenges in its Eastern vicinity (Boonstra \& Shapovalova, 2010).

Against this fragile contextual environment, the EU endorsed the Eastern Partnership (EaP) initiative in 2009. The purpose was to reinforce its footprint in the region as a means to better accomplish the security goals underpinning EU policies eastwards. The main novelty of the EaP is its dual-track approach combining bilateral relations - envisaging EU 
neighbours' political association with and economic integration into the EU - with a multilateral track - supporting regional cooperation and stronger interdependence links amongst EaP partners (European Council, 2009). Of most relevance to power and security relations in the broader European space is the introduction of Association Agreements (AAs), a new political instrument aiming at superseding PCAs as the legal basis for EU relations with the neighbourhood. The underlying goal was "to create a closer relationship between the EU and each of the partner countries to foster their stability and prosperity in our mutual interests" (European Commission, 2008b, p. 3). Far from representing a break with the modus operandi of the ENP, as it continued the tradition of forging relation based on conditionality and socialisation mechanisms conveying the EU's structural power over the neighbourhood, the EaP voices clearly the Union's ambition of becoming a more "proactive and unequivocal actor in the region for security reasons" (European Commission, 2008b, p. 2).

AAs enhanced by Deep and Comprehensive Free Trade Areas (DCFTAs) are arguably instruments of EU structural power with strong impacts on the domestic systems of signatory countries and on their regional setting (Tyushka, 2016). These documents contain detailed and binding provisions on associated countries to align their policies with around $80-90 \%$ of the acquis communautaire, including economic, legal and regulatory convergence with EU standards. Moving far beyond technicalities, AAs are mostly about transforming the quality of democracy, governance and the rule of law of neighbouring countries. Even if no membership is envisaged, associated countries are expected to become EU shadow member states (Wolczuk, 2014). The fact that DCFTAs are hardly beneficial to the EU - since eastern neighbours are relatively insignificant trade partners in the broader scope of EU commercial relations -, sheds light on the political and securityoriented nature of AAs and their ultimate purpose of dragging neighbouring countries into the EU's orbit of influence, something that clashes with Russia's own policies towards the contested neighbourhood, to which this paper now turns.

\section{Russian Policies towards the Post-Soviet Space: In Defence of Moscow's Tradi- tional Sphere of Influence}

Following the dismantling of the Soviet Union in 1991, Russia engaged on complex and simultaneous processes of political, economic, social and identity transition. In the foreign policy domain, an internal debate emerged on what role Russia should perform at the regional and global levels in the post-Cold War context (Dias, 2013, p. 261). After a short period where the willingness to foster close relations with the West and an introspective stance towards the post-Soviet space featured more prominently in Moscow's agenda (Trenin, 2009, p. 8), two clear axis started to give structure to Russia's foreign policies. On the one hand, Russian policies should play to the overarching goal of counterbalancing Western powers' influence in regional and global affairs and of dissuading 
their interference in its traditional sphere of influence. On the other hand, Russia needed to engage in strategies and political arrangements to consolidate its leverage in the postSoviet space (Russian Federation, 1993).

Steadily, Russia developed an assertive and pragmatic foreign policy aiming at reinforcing its hegemonic status in the region by supporting cooperation between member states of the Commonwealth of Independent States (CIS). This focus on its near abroad reflects Russian understandings that domestic and regional security and stability work in tandem and therefore, Moscow can only reach its full potential as a great power if surrounded by friendly regimes, regardless of their political orientations (Joenniemi, 2008; Selezneva, 2003, p. 26). The Foreign Policy Concept of the Russian Federation is clear in this regard, stating that "differences between domestic and external means of ensuring national interests and security are gradually disappearing [... and thus the] development of [...] cooperation with CIS member states constitutes a priority area of Russia's foreign policy" (Russian Federation, 2008).

Here we can identify an important commonality between EU and Russian regional strategies, as both actors rely on the premise of the indissoluble interconnection of internal and external dimensions of security to give body to their foreign policy agendas. Furthermore, as Russia identifies the post-Soviet space as its principal area of influence, it is concerned about external interferences within this region capable of inducing domestic changes unfavourable to Moscow's interests (Judah, Kobzova, \& Popescu, 2011, p. 23). It is in this level of analysis that we can understand Russia's reluctance before the EU's increasing involvement eastwards, as it fears the ability of Brussels to persuade countries in the contested neighbourhood to gravitate around the EU (Dias, 2013, p. 262), something that clashes with Russian ambitions to retain the monopoly of strategic influence in its near abroad (Herd, 2010, p. 14).

Overall, Russia's relations with its vicinity have been based on its comparative advantages and on strategies crosscutting the military, political and economic fields aiming at maximizing gains and minimizing perceived geopolitical losses from the expansion of Western institutions - the EU and the North Atlantic Treaty Organization (NATO). Relations with the near abroad are highly asymmetrical and envisage to perpetrate dependencies in the region favouring the maintenance of Russia as the hegemonic power in the post-Soviet space (Baev, 2007; Dias, 2014). Examples of asymmetric relations of power in the region include the presence of Russian troops in the post-Soviet space and Russia's crucial, though not impartial, role in all the protracted conflicts in the region as a means to provide Moscow with the levers to influence domestic politics in its vicinity and constrain their foreign policy choices (Trenin, 2009, p. 11).

These goals are reinforced by strong and highly unbalanced economic links between Russia and its neighbours. Here attempts at economic integration and increasing interdependence have been reinforced by the acquisition of large shares on the main economic 
sectors in the region and the accentuation of Russia as its neighbours' preferential market and major employer of labour migrants in the post-Soviet space (Tsygankov, 2006, pp. 147148). Within this more economic-oriented seduction strategy, energy has been playing a major role as a toll of positive and negative conditionality. This means that Russia has had a record of rewarding friendly regimes with price reductions and debt pardons, whereas unfriendly regimes have faced consequences such as energy embargoes and enormous price rises (Wolczuk, 2016, p. 3). The politization of energy by Russia had become clear following the gas crises with Ukraine and Belarus since the mid-2000s. Despite arguments presenting these contentions as natural flows of market-related fluctuations, the fact that energy crises in the post-Soviet places tend to match political events unfavourable to Russian interests - e.g. the colourful revolutions of 2004 and 2005 - and that the Russian president often appears as the main interlocutor in the resolution of tensions in this sector, suggests that energy has been used by the Kremlin as a political tool to reinforce its footprint in regional affairs and either reward or punish its neighbouring countries for their foreign policies (Closson, 2009; Makarychev, 2008; Perovic, 2009).

Other important strategies by Russia include the support to pro-Russian political parties and non-governmental organizations in its vicinity and a more recent emphasis on the concept of sovereign democracy as an alternative to the liberal agenda enforced by the EU (Tolstrup, 2009, pp. 932-933). The goal is to present a normative agenda - based on a combination of authoritarian rule, a minimalist understanding of democracy, and the ability to deploy foreign policy strategies regardless of the perceptions and interests of powers outside the post-Soviet space - that can rival with the EU's increasing interference in Russia's traditional area of influence and interests (Finkel \& Brudny, 2012; White, 2012, p. 358) -, thus conferring a strong socialising axis to Russian foreign policies.

Regional integration initiatives reflecting a certain degree of mimicry of EU approaches towards the contested neighbourhood also play a meaningful role in preserving Russian regional advantages by acting as vehicles promoting its interests (Stent, 2008). The first initiative of sorts was the CIS established in 1991 as a means of forging a special socioeconomic and security relations in the former Soviet space. Despite the limited record of regional integration promotion - with only a limited number of member-states endorsing all CIS initiatives -, this organisation has proven to have immense resilience and adaptability to its broader regional environment. Over time its competencies grew in scope and depth and the CIS has now supranational powers in several areas and has opened important avenues for the gradual deepening of economic and military integration in the region. In 2007, a far-reaching concept for the development of this organization was approved to promote long-term political and economic integration in the post-Soviet space, even though only Russia, Belarus, Kazakhstan and Armenia have signed this document (White, 2012, pp. 293). 
The CIS mission has been strictly articulated with other Russian-led regional integration initiatives, such as the Common Security Treaty Organization (CSTO) and the Eurasian Union (EaU). Whereas the former is a political-military alliance relying on the principle of collective security with a paramount role as the motor of security integration in the post-Soviet space, the latter represents a more holistic approach to regional integration. Largely inspired by the EU integration process, the EaU started as a free trade area agreement between Belarus, Kazakhstan and Russia in 1996, but has soon enlarged its objectives to include the creation of a customs union and a single economic space managed at the supranational level, which has come into existence in 2012, as part of a more inclusive project. Officially launched in 2015, the EaU is a regional organisation of economic cooperation envisaging to place Russia at the centre of integration processes in the post-Soviet space and turn it into the privileged rule maker as a means of protecting Russia's hegemonic status in the region - from EU interferences - and of bolstering its identity as the uncontested and historical leader in the former Soviet space. As contended by Tsygankov (2015, p. 291), the EaU is "not strictly an economic arrangement, but also an alternative means of defending sovereignty and national identity from encroachment by the EU'. In this regard, Russia is seemingly reproducing the EU model for regional integration by creating opportunities for cooperation spillover into new areas and fostering the transference of powers from the national to the supranational level - a level where Moscow has a stronger bargaining chip than its neighbours - aiming at reversing the perception that, contrary to the EU, Russia does not provide an attractive model for regional integration and modernization (Averre, 2005, p. 187).

Overall, Russian foreign policies towards the near abroad have combined different instruments and strategies to preserve asymmetrical relations in the post-Soviet space and reaffirm Russia as the uncontested leader in this area. Even if Russian-led initiatives are far from delivering the desired levels of regional integration they are clear in conveying the fundamental strategic role of the post-Soviet space to Moscow's political identity - it is only by controlling and securing events beyond its borders that Russia can assure its internal stability and its affirmation as a meaningful and powerful global player. For this understanding is very similar to that enforced by the EU, it has had important consequences for the unfolding of regional dynamics of power and security, especially in the context of EU-Russia competition over a common area of interests and desired influence, something that the next section argues climaxed into the Ukrainian crisis.

\section{The Collision of EU and Russian Policies towards the Contested Neighbourhood and the Ukrainian Crisis}

Notwithstanding clear differences between the EU and Russia - as the former is a regional organisation with a complex and multi-level system of decision-making and the 
latter is a traditional power with well-defined and focused foreign interests (Casier, 2016, p. 27) - the previous sections revealed both these actors to pursue a very similar approach towards their shared neighbourhood. As the EU and Russia embrace a broad understanding of security, whereby their internal stability and their reliability as global powers are dependent on their ability to control and influence what happens beyond their borders (Nitoiu, 2011, p. 462), their common vicinity emerges as a contested field marred by struggles for power and competing agendas.

This is not to say that the EU and Russia have their backs turn on each other permanently. On the opposite, Brussels and Moscow are keen to recognise the interdependent nature of European security and are willing to cooperate in a number of fields (Headley, 2012, p. 445). Cooperation between the EU and Russia has been initially framed by the PCA ratified in 1997, and has been reinforced by instruments such as the EU Northern Dimension launched in 1999, the EU Common Strategy on Russia approved in 1999, the Russian Medium Term Strategy for Development of Relations between the Russian Federation and the European Union presented in 1999, and the Four Common Spaces established in 2003 under the framework of the existing PCA. These frameworks for relations reflect the understanding that the EU and Russia are strategic partners and that European challenges cannot be addressed without a cooperative and working relationship (Flenley, 2008, pp. 198-199). As a result, since the early 1990s EU-Russia relations have become highly institutionalised and were enlarged to include cooperation in a number of fields, including economic issues, energy, science, technology, education and security (Potemkina, 2010).

However, in areas relating to their common vicinity relations have not been smooth. To initial focus of tension associated with Russian concerns about being treated as a junior partner by the EU, the post-Enlargement regional configuration and Brussels increasing focus on Eastern Europe and the South Caucasus, along Moscow's more assertive and pragmatic agenda under the rule of Vladimir Putin inserted a considerable dose of complexity and contention in EU-Russia relations (Haukkala, 2015). EU neighbouring policies caused considerable distrust amongst political elites in Moscow who saw them as an attempt to extend the EU's power eastwards. This view was derived from and exacerbated by the colourful revolutions in the post-Soviet space signalling a significant shift in terms of EU democracy promotion policies in the region (Gromadzki, et al., 2005, p. 15). EU support to these movements was perceived in Moscow as a revival of the Cold War geopolitical thinking in Europe and EU neighbouring policies were perceived as the source of new challenges and rivalry in the post-Soviet space (Barysch \& Grant, 2004). As Russia is itself eager to strengthen its power and influence towards the region, the ENP and the EaP became cornerstone causes of tension and a motor of tension escalation between Brussels and Moscow. This directed Russia to adopt more assertive and pragmatic approaches towards the region (Trenin, 2008, p. 106), including several energy crisis with neighbours whenever they committed themselves to the path of European integration (Mangott \& Westphal, 2008). 
Russia's negative reaction to the ENP and its related initiatives, and the EU's negative attitude towards Russian-led regional initiatives, confirms the common vicinity as a place of contention where a mutually exclusive understanding of regional integration in this area prevails (Dias, 2013). The speech delivered by Vladimir Putin at the Munich Security Conference in 2007 illustrates an increasing level of tension between Russia and the EU. Expressing dissatisfaction with the existing situation in Kosovo and the United Stated-led anti-missile defence system in Europe, he criticised the civilizational discourse that often supports West interventions and the powerful ambitions underpinning EU and NATO expansion towards Russia's traditional sphere of influence (Putin, 2007).

Another focus of tension emerged with the Russia-Georgia war of 2008. Consequently, the EU suspended negotiations on the new PCA with Russia. However, political dialogue was soon resumed as the EU assumed a mediating role in the conflict (Freire, 2014, p. 44), revealing Brussels' intention to maintain a cooperative string in relations with Russia. At this point, negotiations on a New Basic Agreement were launched in order to provide a more comprehensive framework for EU-Russia cooperation.

Despite this attempt to revive EU-Russia relations, competing trends and discursive practices were now clearly voiced by Brussels and Moscow. At the EU level, it is noticeable a gradual construction of Russia as a threat to European security leading to harsher discourses. In this regard, the Review of EU-Russia relations provides important insights on how the EU perceives its positioning in the ladder of power at the regional level: "The EU can approach its relationship with Russia with a certain confidence. Economically, Russia needs the EU. [...] Russia needs to modernize and diversify its economy. The EU is a natural partner for this process" (European Commission, 2008a, p. 2). This excerpt exposes the asymmetrical nature of EU-Russia relations and the fact that, from the EU's standpoint, Brussels should assume the role of front-runner not only due to Moscow's economic and energy dependence, but also because the Union envisaged to play a meaningful in guiding Russia into proper behaviour at the national, regional and international levels. Furthermore, this document states that the EU should actively pursue its own interests in the context of relations with Russia, while simultaneously condemning the "disproportionate Russian reaction" in Georgia (European Commission, 2008a), thus further acknowledging a contested field in the shared neighbourhood.

The war between Georgia and Russia marked a turning point in EU perceptions of its role in regional security. By reinforcing the image of Russia as a regional threat, it allowed for a greater internal prioritization of the frozen conflicts in the Eastern neighbourhood in the EU's agenda, something that had remain highly under-securitised until that point (Simão \& Dias, 2016, p. 106). As a result, the EU deployed the EU Monitoring Mission in Georgia and took a leading mediating role in the Geneva peace talks. Besides the EU was 
now willing to promote a strategy of engagement without recognition with the separatist states of Eurasia aiming at undermining Russia's strategy of isolating these entities from the international community (Semneby, 2012).

These reinforcement of the EU's footprint in the Eastern neighbourhood triggered more assertive Russian responses in the region and harsher positioning regarding the EU. Moscow was now more vocal in its condemnation of EU neighbouring policies and initiatives concerning their common vicinity. Regarding the launch of the EaP in 2009 as a response to events in the region, then Russian foreign minister Sergei Lavrov accused the EU of carving out a new sphere of influence in Russia's own backyard and creating new dividing lines in Europe (Ria Novosti, 2009). The EU-Russia summit of 2009 exposed even further the mistrust and disagreement between the two sides, when President Medvedev suggested that "the EU itself did not know yet why it needs the Eastern Partnership", even if stressing that he did not want the initiative "to turn into a partnership against Russia" (Radio Free Europe/Radio Liberty, 2009). This echoed in the EU and consolidated a trend labelling Russia as a hostile power relying on Cold War notions of spheres of influence, particularly whenever it tries to block EU neighbouring policies and initiatives (Trenin, 2009, pp. 3-4).

Competition over the contested neighbourhood was revived in March 2012, when Vladimir Putin announced its ambition of creating the EaU as an alternative to European integration and a means to obstruct the Union's growing engagement in its near abroad (Emerson, 2014, p. 5). This competition reached its high point in the context of the Ukrainian crisis. Ukraine's last minute withdrawal from signing the AA/DCFTA with the EU at the EaP summit in Vilnius in November 2013, following a non-transparent meeting with President Vladimir Putin, was mostly perceived in the EU as a flagrant interference by Russia on the country's process of European integration. This caused great frustration in Ukraine's civil society triggering the Euromaidan movement and ultimately leading to the dismissal of President Viktor Yanukovitch and the election of a more pro-European government (Sotiriou, 2016, p. 58). This crisis was perceived by Moscow as a Western-driven "anti-constitutional takeover, an armed seizure of power" (Putin, 2014) directed against Russian interests in the region.

Fierce dissatisfaction in Moscow regarding the Euromaidan movement and claims for further engagement with the EU in Ukraine were translated into increasing support to separatist movements in Eastern Ukraine and the annexation of Crimea in March 2014. To a perceived loss of influence in its neighbourhood, Moscow countered by taking full military control of Crimea, which was followed by a hastily organised referendum on March 16. As a result of this referendum, the peninsula was incorporated into Russian territory thus making Ukraine's loss of this region a fait accompli. A series of uprisings in Eastern Ukraine followed, contributing to the ongoing destabilisation of the country, which was accompanied by an international campaign whereby 
Russia constructed and spread the image of Kiev as a source of regional insecurity with the intended aim to make EU support to and investments in the country less attractive (Haukkala, 2015, p. 34).

Perceiving these events as an EU-led coup aiming at undermining Russian influence in the region, Moscow took an active role in the internal conflict between pro-Europeans and pro-Russians in the country, and provided support to separatist movements in Eastern Ukraine. Along with the annexation of Crimea in March 2014, this enabled Russia to send a clear message to their neighbours - full control of their territories can only be achieved by aligning with Russia, whereas further integration into the EU and NATO will have serious consequences to their territorial integrity (Simão, 2016; Sirbiladze, 2015).

In this regard, the Ukrainian crisis appears as the culmination of a long drift between the EU and Russia regarding their power strategies in the contested neighbourhood. Notwithstanding, the internal dimension of this crisis related to the fragile economic record of the country and a profound popular dissatisfaction with what they perceive to be corrupt political elites, the broader regional scenario cannot be disregarded. Ultimately, the Ukrainian crisis is the clashing point of processes of development and enforcement of two conflicting agendas regarding a common sphere of influence. It is a battle of two regional giants for power and influence in the contested neighbourhood.

Far from representing the end of a process, the Ukrainian crisis has played a pivotal role to the unfolding of competing trends at the regional level. The next section reflects upon this evolution in order to shed light on the features of a new stage of EU-Russia relations and dispute for power in the contested neighbourhood. A stage where the antagonism of EU and Russia regional agendas is now clearly assumed and the demonization of the other becomes clear in political discourses, with serious consequences for the future of European security lato sensu.

\section{EU-Russia Relations During and After the Ukrainian Crisis}

Previous sections reflected upon the competing nature of EU and Russia regional agendas and the dynamics of power and security they produce and reproduce. In that regard, and from a critical standpoint, the Ukrainian crisis is arguably the point where EU and Russia antagonistic projects collided. However, rather than representing the end of a process, events in Ukraine inaugurated a new stage of confrontation between two regional giants. In the post-Ukrainian crisis scenario security concerns and powerful agendas are now more clearly assumed by the EU and Russia. This has had influences in their bilateral relationship, which is currently underpinned by mutual distrust, and perceptions of each other as their respective significant opponent, thus reinforcing the mutually exclusive nature of EU and Russian regional endeavours. As such, a focus on the international dimension of the Ukrainian crisis reveals the moment when the EU and Russia security 
approaches towards the contested neighbourhood clashed, turning the broader European space into a more insecure space.

Ukraine's imposed choice between closer integration with either Moscow or Brussels in 2013 thus took a symbolic dimension. Although both sides denied they were exerting any pressure on Kyiv, in practice a clear and mutually exclusive choice was put to the country: closer European integration meant losing Russia; and closer integration with Moscow meant losing the path of European integration (Casier, 2016, p. 21; Nilsson \& Silander, 2016, p. 55). This is all the most visible in Russian President Vladimir Putin statement when questioned about the possibility of Ukraine simultaneously joining the DCFTA with the EU and the Customs Union with Russia

No, it would not be possible. It would be impossible because that association assumes the creation of a free trade zone between the European Union and Ukraine. Within the framework of that zone, Ukraine takes on the responsibility to implement the European Union's trade rules and trade policy within its territory (Putin, 2013).

The Ukrainian crisis seriously undermined EU-Russia relations and translated itself into the suspension of bilateral cooperation, irregular EU-Russia summits and the interruption of negotiations on a New Basic Agreement superseding the PCA. Furthermore, it instigated the application of a three-tier strategy of sanctions against Russia, to which Moscow responded with a range of counter-sanctions to the EU, thus turning the sanctions dance into an economic warfare. Following the Ukrainian crisis and the applications of sanctions to Russia, developments in the economy of the country were mainly negative with a significant role also played by the fall of oil prices (Davis, 2016). However, the official discourse in the Kremlin undervalues the negative impact of EU sanctions preferring to see them as an opportunity to revamp Russian agricultural and resource output, and domestic production (Euronews, 2017).

More than expanding Russia's effective control beyond its borders, more muscular initiatives in the neighbourhood as a response to perceived strategic advances of external powers - e.g. the Russian-Georgian War of August 2008, the ensuing recognition of South Ossetia and Abkhazia, and the annexation of Crimea in 2014 and the ongoing support to rebels in Luhansk and Donetsk - are sending a clear message to the EU that Moscow will not tolerate any interference in its traditional sphere of influence (Laenen, 2012, p. 26).

Against this scenario, the EU was keen to adapt its discursive practices. The trend has been to reinforce the EU's hegemonic regional role, for it believes this is the only route to strengthen its global actorness and to preserve regional security essential to its internal prosperity. Tumultuous events in the neighbourhood are now portrayed not as a failure of EU foreign and neighbourhood policies or of insufficient instruments and ineffective 
application, but as the result of lacking and insufficiently strong engagement in the EU's vicinity - "if we want to promote a more peaceful world, we will need more Europe and more Union in our foreign policy" (Juncker, 2015, p. 20). The EU's commitment to promoting peace and security across Europe, assumes now a more confrontational tone regarding Russia's interventions in the shared neighbourhood. The European Commission makes clear that "the security and the borders of EU Member States are untouchable" and that this should "be understood very clearly in Moscow" (Juncker, 2015, p. 21). Whenever Russia endangers the European political environment, the EU will be prepared to show it the cost of confrontation, namely via sanctions. With this bold and pragmatic line of action, the EU envisages to take a leading role on regional matters and reinforce the Europeanisation of its neighbours. The latest review of the ENP consolidated the understanding of Russia as a threat to European security and takes notice of the deterioration of EU-Russia relations as a result of the illegal annexation of Crimea and the destabilisation of Eastern Ukraine (European Commission and High Representative of the Union for Foreign Affairs and Security Policy, 2015).

Against a scenario of increasing instability at its borders the EU responded with mechanisms of political stabilisation and economic aid but also with the deployment of an Advisory Mission on civilian security reform under the framework of the Common Security and Defence Policy (European Council, 2015, p. 8), although the EU's overall response to the Ukrainian crisis can be interpreted as too little, too late, particularly from the perspective of Ukrainian elites, who have been demanding a more active role by the EU in the resolution of this crisis and in adopting a more punitive stance towards Russia's aggressive regional manoeuvres (Yushchenko, 2014).

\section{Conclusion}

EU-Russia relations have been traditionally characterised by a dichotomy between strategic cooperation and rising antagonism over their common neighbourhood (Averre, 2009; Nitoiu, 2016). Political dialogue appears to be trapped on Russian accusations of EU interferences in its internal affairs and its traditional area of influence, and EU uneasiness about

Russian undemocratic practices and muscular approach towards its near abroad. The mixing of competing and cooperative strings in EU-Russia relations means that both Russia and the EU acknowledge the relevance of the other and strategic benefits from mutual understanding and cooperation, but they also recognise entrenched differences and incompatibilities on their understandings and regional approaches (Freire, 2008, p. 54). One of the greatest causes of tension between Brussels and Moscow is the shared neighbourhood, which appears as a contested field of struggles for power and the ultimate stage of competition between their respective regional initiatives. 
Contentions over the shared neighbourhood do not mean that the EU and Russia have their backs turned on each other permanently, for both sides recognise the need to cooperate in strategic fields due to the intricate nature of security threats. However, struggles for power and security dynamics between the EU and Russia have often been more visible in forms different from a cooperative one, whenever their privileged interests - the need to secure their regional setting as a condition for internal security and stability - are on the table, revealing that EU-Russia relations result from the sensitive and difficult balance between a strategic partnership with a cooperative tone and a regional competition for power and security.

Both parties understand their own policies as an inevitable response to the threatening initiatives of the other. EU and Russian policies thus come across as manoeuvres of adjustment to an evolving political, economic and security context at their borders. Consequently, both Brussels and Moscow attempt to block each other strategies in the region because they perceive their approaches towards this space as mutually exclusive. In that regard, EU and Russian foreign policies are created in tandem, resulting from a complex process of cooperation in key sectors and a strategic competition over a common area of influence. This simultaneously reinforces the hegemonic nature of their regional processes, propels the ongoing processes of securitisation of their shared neighbourhood and adds to the competitiveness and mutual distrust that underpins their relations and regional dynamics of power and security. The outcome is a struggle for power in the region resulting from, and intensifying, processes of securitisation in the shared neighbourhood, that reached its peak during the Ukrainian crisis, something that rather than fulfilling the security interests of the EU and Russia has raised awareness for the fragility of European security and the need for an open and working dialogue between these two regional giants if European peace is to be preserved.

This is particularly conspicuous in the post-Ukrainian crisis context, which triggered a move from tense but cooperative relations to a much more antagonistic pattern of relations. To some degree, events in Ukraine can be interpreted as a proxy conflict between the EU and Russia (Haukkala, 2015, p. 37). This sheds light on the interconnectedness, multiple and often clashing articulations of power and security dynamics in the EU-Russia-shared neighbourhood triangle, not without consequences to the unfolding of EU and Russian hegemonic agendas and the broader European security.

Ironically, and despite the security-oriented rationale underpinning both EU and Russian strategies towards the contested neighbourhood, struggles for power in this space raised regional insecurity to more dangerous levels. Attempts made to provide a solution to the annexation of Crimea and the confrontations in Donetsk and Luhansk, namely under the so-called Minsk agreements, failed to provide any working schemes for conflict resolution and transformation. So far levels of tension in Eastern Ukraine remain high, and the death toll from mid-April 2014 stands at nearly 10000 with another almost 23000 people injured (Center for Strategic and International Studies, 2016; Office of the 
United Nations High Commissioner for Human Rights, 2016). This pressing scenario makes it urgent to critically think about the results of antagonistic views on the future of Europe and on the need to create new mechanisms for dialogue and effective cooperation based on a comprehensive and inclusive - rather than self-centred and exclusive - understanding of security and the interconnected relationship between internal and external stability, not only between Brussels and Moscow, but also between them and the subject of their powerful strategies: the countries in the shared neighbourhood.

\section{References}

ATTINÀ, Fulvio - European Neighbourhood Policy and the Building of Security around Europe. In ATTINÀ, Fulvio, \& ROSSI, Rosa (Eds.) - European Neighbourhood Policy: Political, Economic and Social Issues. Catania: The Jean Monnet Centre Euro med, 2004. pp. 16-24 [accessed on 24 October 2017]. Available at https://biblio.ugent.be/ publication/601060/file/6816899.

AVERRE, Derek - Russia and the European Union: Convergence or Divergence? European Security, Vol. 14: No. 2 (2005), pp. 175-202.

AVERRE, Derek - Competing Rationalities: Russia, the EU and the 'Shared Neighbourhood', Europe-Asia Studies, Vol 61: No. 10 (2009), pp. 1689-1713.

AVERRE, Derek - The EU, Russia and the shared neighbourhood: security, governance and energy. European Security, Vol. 19: No. 4 (2010), pp. 531-534.

BAEV, Pavel - Russia Aspires to the Status of 'Energy Superpower', Strategic Analysis. Vol. 31: No. 3 (2007), pp. 447-465.

BARYSCH, Katinka, \& GRANT, Charles - Russia, the EU and Ukraine: not a tug of war. Centre for European Reform Briefing Note. London: Centre for European Reform, 2004 [accessed on 24 October 2017]. Available at http://www.cer.org.uk/sites/default/files/ publications/attachments/pdf/2011/briefing_ukraine_dec04-1251.pdf.

BOEDELTJE, Freerk \& VAN HOUTUM, Henk - Brussels is Speaking: The Adverse Speech Geo-Politics of the European Union Towards its Neighbours. Geopolitics, Vol. 16: No. 1 (2011), pp. 130-145.

BOONSTRA, Jos \& SHAPOVALOVA, Natalia - The EU's Eastern Partnership: One year backwards. Fride Working Paper No. 99, 2010, pp. 1-13.

BÖRZEL, Tanja; STAHN, Andreas \& PAMUK, Yasemin - The European Union and the fight against corruption in its near abroad: can it make a difference? Global Crime, Vol. 11: No. 2 (2010), pp. 122-144.

CASIER, Tom - Are the policies of Russia and the EU in their shared neighbourhood doomed to clash?, in KANET, Roger and FREIRE, Maria Raquel (Eds.) - Competing for Influence: The EU and Russia in post-Soviet Eurasia. The Netherlands: Republic of Letters, 2012, pp. 31-53. 
CASIER, Tom - Identities and Images of Competition in the Overlapping Neighbourhoods: How EU and Russian Foreign Policies Interact, in PIET, Rémi and SIMÃO, Lícinia (Eds.) - Security in Shared Neighbourhoods: Foreign Policy of Russia, Turkey and the EU. Hampshire: Palgrave Macmillan, 2016, pp. 13-34.

CENTER FOR STRATEGIC STUDIES - The Ukrainian crisis timeline. [accessed on 24 October 2017]. Available at http://ukraine.csis.or/\#426.

CHRISTOU, George - European Union security logics to the east: the European Neighbourhood Policy and the Eastern Partnership. European Security, Vol. 19: No. 3 (2010), pp. 413-430.

CIANCIARA, Agnieszka - Stability, security, democracy: explaining shifts in the narrative of the European Neighbourhood Policy. Journal of European Integration, Vol. 39: No. 1 (2017), pp. 49-62.

CLOSSON, Stacy - Russia's key customer: Europe. In PEROVIC, Jeronim, ORTTUNG, Robert \& WENGER, Andreas (Eds.) - Russian Energy Power and Foreign Relations: Implications for conflict and cooperation. London: Routledge, 2009, pp. 89-108.

DAVIS, Christopher - The Ukraine conflict, economic-military power balances and economic sanctions, Post-Communist Economies, Vol. 28: No. 2 (2016), pp. 167-198.

DIAS, Vanda Amaro - The EU and Russia: Competing Discourses, Practices and Interests in the Shared Neighbourhood. Perspectives on European Politics and Society, Vol. 14: No. 2 (2013), pp. 256-271.

DIAS, Vanda Amaro - As relações da Rússia com a Ucrânia, Bielorrússia e Moldova: poder, dependências e assimetrias no espaço pós-soviético, in DAEHNHARDT, Patricia and FREIRE, Maria Raquel (Eds.) - A Politíca Externa Russa No Espaço Euro-Atlântico: dinâmica de cooperação e competição num espaço alargado. Coimbra: Coimbra University Press, 2014, pp. 57-84.

EMERSON, Michael - After the Vilnius fiasco: Who is to blame? What is to be done? CEPS Essay. Brussels: Centre for European Policy Studies. No. 8, 2014. pp. 1-19.

EURONEWS - Putin extends sanctions against the EU. Euronews. June 30, 2016 [accessed on 24 October 2017]. Available at http://www.euronews.com/2017/06/30/putin-extends-russian-counter-sanctions-against-eu-until-end-of-2018-tass.

EUROPEAN COMMISSION - Wider Europe - Neighbourhood: proposed new framework for relations with the EU's Eastern and Southern Neighbours. IP/03/358. Brussels: European Commission, 2003.

EUROPEAN COMMISSION - Communication from the Commission: European Neighbourhood Policy - Strategy Paper. COM (2004) 373 final, 2004.

EUROPEAN COMMISSION - Communication from the Commission to the Council: Review of EU-Russia relations. COM (2008) 740 final, 2008a.

EUROPEAN COMMISSION - Communication from the Commission to the European Parliament and the Council - Eastern Partnership. COM (2008) 823 final, 2008b. 
EUROPEAN COMMISSION; \& HIGH REPRESENTATIVE OF THE EUROPEAN UNION FOR FOREIGN AFFAIRS AND SECURITY POLICY - Joint Communication to the European Parliament, the Council, the European Economic and Social Committee and the Committee of the Regions: Review of the European Neighbourhood Policy. SWD (2015) 500 final. 2015.

EUROPEAN COUNCIL - A Secure Europe in a Better World: European Security Strategy. Brussels, December 12, 2003.

EUROPEAN COUNCIL - Joint Declaration of the Prague Eastern Partnership Summit. 8435/09 (Presse 78). Prague, May 7, 2009.

EUROPEAN COUNCIL - Joint Declaration of the Eastern Partnership Summit. Riga, May 21-22, 2015.

FINKEL, Evgeny, \& BRUDNY, Yitzhak - Russia and the colour revolutions. Democratization, Vol. 19: No. 1 (2012), pp. 15-36.

FLENLEY, Paul - Russia and the EU: The Clash of New Neighbourhoods?. Journal of Contemporary European Studies, Vol. 16: No. 2 (2008), pp. 189-202.

FREIRE, Maria Raquel - Two unequal partners: the EU and its Russian neighbor, in BARRINHA, André (Ed.) - Towards a Global Dimension: EU's Conflict Management in the Neighbourhood and Beyond. Lisbon: Fundação Friedrich Ebert, 2008, pp. 51-64.

FREIRE, Maria Raquel - A Evolução da Política Externa da Rússia. In DAEHNHARDT, Patricia and FREIRE, Maria Raquel (Eds.) - A Politíca Externa Russa No Espaço EuroAtlântico: dinâmica de cooperação e competição num espaço alargado. Coimbra: Coimbra University Press, 2014, pp. 29-55.

GHAZARYAN, Narine - The ENP and the Southern Caucasus: Meeting the Expectations?, in WHITMAN, Richard and WOLFF, Stefan (Eds.) - The European Neighbourhood Policy in Perspective: Context, Implementation and Impact. New York: Palgrave Macmillan, 2010, pp. 223-246.

GROMADZKI, Grzegorz; SUSHKO, Oleksandr; VAHL, Marius; WOLCZUK, Kataryna \& WOLCZUK, Roman - Will the Orange Revolution bear fruit? EU-Ukraine relations in 2005 and the beginning of 2006. Warsaw: Stefan Batory Foundation, 2005.

HAUKKALA, Hiski - From Cooperative to Contested Europe? The Conflict in Ukraine as a Culmination of a Long-Term Crisis in EU-Russia Relations, Journal of Contemporary European Studies, Vol. 23: No. 1 (2015), pp. 25-40.

HEADLEY, James - Is Russia Out of Step with European Norms? Assessing Russia's Relationship to European Identity, Values and Norms Through the Issue of Self-Determination, Europe-Asia Studies, Vol. 64: No. 3 (2012), pp. 427-447.

HERD, Graeme - Security Strategy: Sovereign Democracy and Great Power Aspirations. In GALEOTTI, Mark (Ed.) - The Politics of Security in Modern Russia. Surrey: Ashgate Publishing Limited, 2010, pp. 7-27. 
JOENNIEMI, Pertti - Border issues in Europe's North, in Diez, Thomas; ALBERT, Mathias and STETTER, Stephan (Eds.) - The European Union and Border Conflicts: The power of integration and association. Cambridge: Cambridge University Press, 2008, pp. 129-172.

JUDAH, Ben; KOBZOVA, Jana and POPESCU, Nicu - Dealing with a Post-BRIC Russia. London: European Council on Foreign Relations, 2011.

JUNCKER, Jean-Claude - Authorised State of the Union Address 2015: Time for Honesty, Unity and Solidarity. Strasbourg: European Commission, September 9, 2015.

KUZIO, Taras - Transition in Post-Communist States: Triple or Quadruple? Politics, Vol. 21: No. 3 (2001), pp. 168-177.

LAENEN, Ria - Russia's 'Vital and Exclusive' National Interests in the Near Abroad, in FREIRE, Maria Raquel and KANET, Roger (Eds.) - Russia and its Near Neighbours: Identity, Interests and Foreign Policy. London: Palgrave Macmillan, 2012, pp. 17-38.

MAKARYCHEV, Andrey - Russia's Search for International Identity Through the Sovereign Democracy Concept, The International Spectator, Vol. 43: No. 2 (2008), pp. 49-62.

MANGOTT, Gerhard \& WESTPHAL, Kirsten - The Relevance of the Wider Black Sea Region to EU and Russian Energy Issues, in HAMILTON, Daniel and MANGOTT, Gerhard (Eds.) - The Wider Black Sea Region in the 21st Century: Strategic, Economic and Energy Perspectives. Washington D.C.: Center for Transatlantic Relations, 2008, pp. 147-176.

NILSSON, Martin \& SILANDER, Daniel - Democracy and Security in the EU's Eastern Neighborhood? Assessing the ENP in Georgia, Moldova, and Ukraine. Democracy and Security, Vol. 12: No. 1 (2016), pp. 44-61.

NITOIU, Cristian - Reconceptualizing 'Cooperation' in EU-Russia Relations. Perspectives on European Politics and Society, Vol. 12: No. 4 (2011), pp. 462-476.

NITOIU, Cristian - Towards conflict or cooperation? The Ukraine crisis and EU-Russia relations. Southeast European and Black Sea Studies, Vol. 16: No. 3 (2016), pp. 375-390.

OFFICE OF THE UNITED NATIONS HIGH COMMISSIONER FOR HUMAN RIGHTS - Report on the human rights situation in Ukraine: 16 August to 15 November 2016. Geneva: Office of the United Nations High Commissioner for Human Rights.

PARTNERSHIP AND COOPERATION AGREEMENT BETWEEN THE EUROPEAN COMMUNITIES AND THEIR MEMBER STATES, AND UKRAINE. OJ L 49/3 3-39. 1998.

PATTEN, Chris \& SOLANA, Javier - Wider Europe: Joint Letter by the EU External Relations Commissioner and the EU High Representative for CFSP to the Danish Presidency, August 7, 2002 [accessed on 24 October 2017]. Available at http://europa.eu.int/ comm/world/enp/pdf/0130163334_001_en.pdf.

PEROVIC, Jeronim - Introduction: Russian energy power, domestic and international dimensions, in PEROVIC, Jeronim; ORTTUNG, Robert and WENGER, Andreas (Eds.) 
- Russian Energy Power and Foreign Relations: Implications for Conflict and Cooperation. London: Routledge, 2009, pp. 1-20.

POTEMKINA, Olga - EU-Russia cooperation on the common space of freedom, security and justice - a challenge or an opportunity? European Security, Vol. 19: No. 4 (2010), pp. 551-568.

PRODI, Romano - A Wider Europe: A Proximity Policy as the key to stability. SPEECH/02/619, Brussels. December 5-6, 2002.

PUTIN, Vladimir - Putin's Prepared Remarks at 43rd Munich Conference on Security Policy. The Washington Post. February 12, 2007. [accessed on 24 October 2017]. Available at http:// www.washingtonpost.com/wp-dyn/content/article/2007/02/12/AR2007021200555.html.

PUTIN, Vladimir - Press Conference following Supreme Eurasian Economic Council meeting. Minsk. October 24, 2013. [accessed on 24 October 2017]. Available at http:// en.kremlin.ru/events/president/transcripts/press_conferences/19485.

PUTIN, Vladimir - Vladimir Putin answered journalists' questions on the situation in Ukraine. Moscow, March 4, 2014. [accessed on 24 October 2017]. Available at http:// en.kremlin.ru/events/president/transcripts/press_conferences/20366.

RADIO FREE EUROPE/RADIO LIBERTY - At EU-Russia summit, signs of strategic division, not strategic partnership. Radio Free Europe/Radio Liberty, May 22, 2009. [accessed on 24 October 2017]. Available at http://www.rferl.org/content/At_EURussia_ Summit_Signs_Of_Strategic_Division_Not_Strategic_Partnership/1737474.html.

RIA NOVOSTI - EU's Eastern Partnership program not against Moscow - Lavrov. Ria Novosti, April 28, 2009. [accessed on 24 October 2017]. Available at http://en.rian.ru/ russia/20090428/121350475.html.

RUSSIAN FEDERATION - Foreign Policy Concept. 1993.

RUSSIAN FEDERATION - Foreign Policy Concept. 2008.

SELEZNEVA, Liudmilla - Post-Soviet Russian Foreign Policy: Between Doctrine and Pragmatism, European Security, Vol. 11: No. 4 (2012), pp. 10-28.

SEMNEBY, Peter - The EU, Russia and the South Caucasus - Building Confidence. Russia in Global Affairs, No. 1 (March 25, 2012). [accessed on 24 October 2017]. Available at http://eng.globalaffairs.ru/number/The-EU-Russia-and-the-South-Caucasus-Building-Confidence-15507.

SIMÃO, Licínia - The Ukrainian conflict in Russian foreign policy: Rethinking the interconnections between domestic and foreign policy strategies, Small Wars \& Insurgencies, Vol. 27: No. 3 (2016), pp. 491-511.

SIMÃO, Licínia and DIAS, Vanda Amaro - The Securitisation of the EU's Eastern Neighbourhood: What Role for Russia?, in RÉMI, Piet and SIMÃO, Licínia (Eds.) - Security in Shared Neighbourhoods: Foreign Policy of Russia, Turkey and the EU. New York: Palgrave Macmillan, 2016, pp. 97-118. 
SIRBILADZE, Irakli - The Crises of Russian Hegemony in the Post-Soviet Space. New Eastern Europe. March 5, 2015. [accessed on 24 October 2017]. Available at http://www. neweasterneurope.eu/articles-and-commentary/1515-the-crises-of-russian-hegemony-inthe-post-soviet-space.

SOTIRIOU, Stylianos - The irreversibility of history: the case of the Ukrainian crisis (2013-2015), Southeast European and Black Sea Studies, Vol. 16: No. 1 (2016), pp. 51-70.

STENT, Angela - Restoration and Revolution in Putin's Foreign Policy, Europe-Asia Studies, Vol. 60: No. 6 (August 2008), pp. 1089-1106.

TOLSTRUP, Jakob - Studying a negative external actor: Russia's management of stability and instability in the 'Near Abroad', Democratization, Vol. 16: No. 5 (2009), pp. 922-944.

TRENIN, Dmitri - Russia's Perspective on the Wider Black Sea Region, in HAMILTON, Daniel and MANGOTT, Gerhard (Eds.) - The Wider Black Sea Region in the 21st Century: Strategic, Economic and Energy Perspectives. Washington D.C.: Center for Transatlantic Relations, 2008, pp. 103-117.

TRENIN, Dmitri - Russia's Spheres of Interest, not Influence, The Washington Quarterly, Vol. 32: No. 4 (2009), pp. 3-22.

TSYGANKOV, Andrei - Vladimir Putin's last stand: the sources of Russia's Ukraine policy, Post-Soviet Affairs, Vol. 31: No. 4 (2015), pp. 279-303.

TSYGANKOV, Andrei - If not by tanks, then by banks? The role of soft power in Putin's foreign policy, Europe-Asia Studies, Vol. 58: No. 7 (2006), pp. 1079-1099.

TYUSHKA, Andriy - Building the neighbours: the EU's new Association Agreements and structural power in the Eastern neighbourhood, Journal of Contemporary Central and Eastern Europe, Vol. 25: No. 1 (2017), pp. 45-61.

WHITE, Stephen - Understanding Russian Politics. Cambridge: Cambridge University Press, 2012.

WOLCZUK, Kataryna - Ukraine and the EU: Turning the Association Agreement into a success story, Policy Brief. Brussels: European Policy Centre, April 23, 2014. [accessed on 24 October 2017]. Available at www.epc.eu/documents/uploads/pub_4360_ukraine_ and the_eu.pdf.

WOLCZUK, Kataryna - Managing the flows of gas and rules: Ukraine between the EU and Russia, Eurasian Geography and Economics, Vol. 57: No. 1 (2016), pp. 113-137.

YUSHCHENKO, Viktor - Yushchenko, hero of Ukraine's Orange Revolution warns Europe that Putin won't stop at Crimea. McClatchyDC. March 27, 2014. [accessed on 24 October 2017]. Available at http://www.mcclatchydc.com/news/nation-world/article24765781.html. 